\title{
Colonization of vines by Petri disease fungi, susceptibility of rootstocks to Phaeomoniella chlamydospora and their disinfection
}

\author{
Colonização de videiras pelos fungos da doença de Petri, suscetibilidade de \\ porta-enxertos ao fungo Phaeomoniella chlamydospora e sua desinfecção
}

\author{
Ana Beatriz Monteiro Ferreira', Luís Garrigós Leite', José Luiz Hernandes², Ricardo Harakava ${ }^{3}$, \\ Carlos Roberto Padovani ${ }^{4}$, César Junior Bueno ${ }^{1 *}$
}

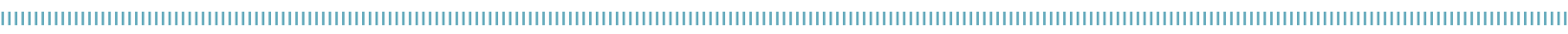

\begin{abstract}
Petri disease is complex, attacks young vine plants and it is difficult to be controlled. The fungus Phaeomoniella chlamydospora $(P h c)$ has been identified as the main causative agent of this disease. This study aimed to evaluate the prevalent colonization of the Petri disease fungi in different portions of vine plants; to assess the susceptibility of grapevine rootstocks to the fungus $P$. chlamydospora; to assess the effect of solarization and biofumigation, followed by hot-water treatment (HWT), on the disinfection of cuttings of the rootstock IAC 766 infected with $P$. chlamydospora, and assess the effect of solarization and biofumigation, followed by HWT, on the rooting of cuttings of the rootstock IAC 766. For the prevalent colonization test, the fungus species detected and identified in 'Niagara Rosada' grafted on two rootstocks different were $P h c$ and Phialemoniopsis ocularis. This is the first report of $P$. ocularis in a young vineyard in Brazil. Both fungi, in particular $P h c$, colonized only the plant's basal part, drawing attention to the rootstock as target for control measures. Measurement of the dark streaks in the vascular system revealed that Golia was the least susceptible rootstock, and IAC 572 was the most susceptible to Phc. Moreover, biofumigation or temperature of $37^{\circ} \mathrm{C}$ applied for 7 and 14 days, both followed by HWT, suppressed $P h c$ in cuttings of the rootstock IAC 766 without hampering their rooting. Meanwhile, new studies are needed to validate the efficiency of these disinfection techniques.
\end{abstract}

KEYWORDS: Petri disease; propagating material; control; resistance; Vitis L.

\begin{abstract}
RESUMO: A doença de Petri é complexa, ataca plantas jovens de videira e é difícil de ser controlada. O fungo Phaeomoniella chlamydospora é o principal agente causal dessa doença. Os objetivos deste estudo foram: avaliar o local prevalente dos fungos da doença de Petri, em diferentes partes de plantas de videira; avaliar a suscetibilidade de porta-enxertos de videira para o fungo P. chlamydospora; avaliar o efeito da solarização e da biofumigação seguido de tratamento com água quente sobre a desinfecção de estacas do porta-enxerto IAC 766 infectadas com o fungo P. chlamydospora; avaliar o efeito da solarização e da biofumigação seguido de tratamento com água quente sobre o enraizamento de estacas do porta-enxerto IAC 766. Para o teste de colonização, as espécies de fungos detectadas e identificadas em Niagara Rosada enxertada em dois porta-enxertos diferentes foram $P$. chlamydospora e Phialemoniopsis ocularis. Este é o primeiro relato de P. ocularis em parrerais jovens de videira no Brasil. Ambos os fungos, em particular P. chlamydospora, colonizaram somente a parte basal das plantas, destacando-se os porta-enxertos como foco para medidas de controle. Medidas das estrias escuras no sistema vascular revelaram que Golia foi o porta-enxerto menos suscetível, e o IAC 572 foi o mais suscetíveis para $P$. chlamydospora. Além disso, a biofumigaçáo ou a temperatura de $37^{\circ} \mathrm{C}$ aplicadas por 7 e 14 dias seguidas de tratamento com água quente eliminaram $P$. chlamydospora em estacas do porta-enxerto IAC 766 sem afetar o enraizamento. No entanto, novos estudos são necessários ainda para validar a eficiência dessas técnicas de desinfecção.
\end{abstract}

PALAVRAS-CHAVE: doença de Petri; material de propagação; controle; resistência; Vitis L. 


\section{INTRODUCTION}

Petri disease causes decline and dieback of grapevines, mainly in young vines. It is a complex disease, and therefore difficult to be controlled. This disease is caused by combination of Phaeomoniella chlamydospora (W. Gams, Crous, M. J. Wingf $\&$ L. Mugnai Crous \& W. Gams) and several species of Phaeoacremonium, and also by Cadophora lutea-olivaceae (F. H. Beyma) T.C. Harrington \& McNew. However, P. chlamydospora is more often associated with typical symptoms of Petri disease, causing the largest lesions and being more frequently re-isolated compared to other fungi related to this disease (GRAMAJE et al. 2011; HALLEEN et al., 2007; MOSTERT et al., 2006; MUGNAI et al., 1999). Other genera of fungi that might be associated to the decline in nurseries or in young vineyards are Acremonium (A. charticola and A. ochraceum) and Phialemoniopsis curvata (= Phialemonium curvatum) (HALLEEN et al., 2007; PERDOMO et al., 2013).

External symptoms of the Petri disease show late budbreak, stunted shoot growth, reduced vegetative vigor, shortened internodes, lower stem diameter, interveinal chlorosis, foliage with necrotic margins, premature defoliation, wilting, and dieback. Internal symptoms (xylem vessel) of the trunk show black spots and black streaking, tyloses and black gums (AROCA; RAPOSO, 2009; GRAMAJE; ARMENGOL, 2011; MOSTERT et al., 2006; MUGNAI et al., 1999).

Petri disease has been reported in different parts of the world where grapevine is cultivated (ABREO et al., 2011; CROUS; GAMS, 2000). In Brazil, Petri disease pathogens were found in the state of Rio Grande do Sul (GARRIDO et al., 2004) as well as in the Northeast region of the country (CORREIA et al., 2013).

LORENA et al. (2001) inoculated P. chlamydospora in the root of Paulsen 1103 rootstock and observed that the fungus colonization differed between vine plant portions, being greatest at the root collar level and at the base of the stem, becoming less frequent and disappearing above the $7^{\text {th }} / 8^{\text {th }}$ internode. Thus, the Petri disease pathogens will colonize mostly the rootstocks in grafted vine plants.

Rootstocks and scions of grapevines are susceptible to the Petri disease pathogens (GRAMAJE; ARMENGOL, 2011); however, some grapevine rootstocks inoculated with C. luteo-olivacea, Phaeoacremonium spp. and P. chlamydospora have shown to be less susceptible in field conditions (GRAMAJE et al., 2010), suggesting the necessity of new studies to verify the susceptibility of different rootstocks to the Petri disease pathogens.

The main sources of inoculum of the Petri disease fungi are infected propagation material, processes for propagation of grapevine plants, infected mother vines, infested soils, and aerial inoculum (AROCA et al., 2010; MOSTERT et al., 2006; MUGNAI et al., 1999). To avoid the dissemination of Petri disease fungi in the field, new studies should be carried out with the purpose of disinfecting rootstock cuttings for the production of healthy mother vines and, consequently, to obtain healthy planting material.

A controversial measure to control Petri disease fungi in grapevine dormant cutting is the hot-water treatment (HWT) (GRAMAJE et al., 2009; ROONEY; GUBLER, 2001). Another measure with potential to disinfect grapevine dormant cutting is biofumigation, a sustainable method for disinfesting the soil. Biofumigation generates anaerobic conditions, toxic volatile compounds (isothiocynates), high temperature (GOPI et al., 2016), and all these factors can weaken or eliminate soilborne phytopathogenic fungi and their resistant structures. Solarization and biofumigation can be simulated in glass flasks kept in a growth chamber, providing an environment that is called microcosm (BUENO et al., 2004). So far, there is no study assessing the effect of biofumigation and solarization in a microcosm, tested solely or complemented with HWT, for the control of Petri disease fungi in rootstock cuttings.

Thus, this study aimed to:

1. evaluate the prevalent colonization of the Petri disease fungi in different portions of vine plant;

2. assess the susceptibility of grapevine rootstocks to the fungus $P$. chlamydospora;

3. assess the effect of solarization and biofumigation in microcosm, followed by hot-water treatment (HWT), on the disinfection of cuttings of the rootstock IAC 766 infected with $P$. chlamydospora, and

4. assess the effect of solarization and biofumigation in a microcosm, followed by HWT, on the rooting of cuttings of the rootstock IAC 766.

\section{MATERIAL AND METHODS}

\section{Colonization of vines by Petri disease fungi}

This study aimed to assess the portions with the most prevalence for colonization of Petri disease fungi in vine plants: the basal part (rootstock), the stem part ( $40 \mathrm{~cm}$ above the basal part), or the branch part ( $40 \mathrm{~cm}$ far from stem part). To this end, three entire plants of 'Niagara Rosada' grapevine (Vitis labrusca L. $\mathrm{x}$ Vitis vinifera L.) grafted on the rootstock Ripária do Traviú ( 3 years old) and three plants grafted on the rootstock IAC 766 ( 2 years old) were collected randomly in a commercial vineyard infected with Petri disease, in the municipal-

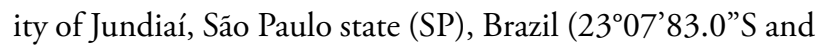
$\left.46^{\circ} 56^{\prime} 85.3^{\prime \prime} \mathrm{W}\right)$. Thus, three treatments and three replications were established, represented by the three parts of each plant, and by the three plants of each variety, respectively.

For each plant part, $4 \mathrm{~cm}$-long samples from the vascular system were taken and superficially disinfected by immersing 
them for 30 seconds in $70 \%$ alcohol and $1 \mathrm{~min}$ in a 1.5\% solution of sodium hypochlorite, followed by immersion in sterile distilled water. Then, the samples were dried on sterile filter paper and cut into smaller fragments $(0.5 \mathrm{~cm})$ with a sterile scalp. The samples were distributed in Petri dishes, using 4 fragments per dish and 15 dishes per each plant part.

The Petri dishes were incubated in a growth chamber under $23^{\circ} \mathrm{C}$ for a 12 -hour photoperiod for 21 days. The incidence of the Petri disease pathogens was expressed as the percentage of infected fragments per each plant part.

\section{Identification of the Petri disease fungi}

The isolates of the Petri disease that grew in the medium were processed according to CORREIA et al. (2013) for molecular identification. After this, DNA was extracted by following the CTAB method described by DOYLE; DOYLE (1987). The polymerase chain reaction (PCR) was performed to amplify the ITS- $5.8 \mathrm{~S}$ region of the rDNA with the oligonucleotide primers ITS1 (5'-TCCGTAGGTGAACCTGCGG-3') and ITS4 (5'-TCCTCCGCTTATTGATATGC-3') (WHITE et al., 1990). Fragments of the beta tubulin gene ( $\beta$ Tubulin) were amplified with the pair of primers Bt2a (5'-GGTAACCAAATCGGTGCTGCTTTC-3') and Bt2b (5'-ACCCTCAGTGTAGTGACCCTTGGC-3') of GLASS; DONALDSON (1995) and Btub-F: AAGGGHCAYTAYACYGARGG and Btub-R: CATGTTGGACTCDGCCTC of LAZAROTTO et al. (2014). The reactions were performed in a PTC100 thermocycler (MJ Research) according to the following protocol: initial denaturation at $94^{\circ} \mathrm{C} / 2 \mathrm{~min}, 40$ cycles of $94^{\circ} \mathrm{C} / 30 \mathrm{~s}-$ $54^{\circ} \mathrm{C} / 30 \mathrm{~s}-72^{\circ} \mathrm{C} / 60 \mathrm{~s}$, and final extension at $72^{\circ} \mathrm{C} / 4 \mathrm{~min}$. The PCR products were purified by precipitation with polyethylene glycol, according to a protocol described by SCHMITZ; RIESNER (2006). Sequencing was performed by the chain termination method with the reagent BigDye 3.1 (Applied Biosystems) and ABI3500 automatic sequencer (Applied Biosystems).

Nucleotide alignment was carried out by MUSCLE program (EDGAR; MUSCLE, 2004). Phylogenetic trees were built by the Neighbor Joining method using the MEGA 6.0 program, with evaluation of the topology's reproducibility through bootstrap with 1,000 repetitions. The support value obtained for each branch of the tree is shown in Figure 1, not adopting a minimum value to separate the branches.

\section{Susceptibility of rootstocks to the fungus $P$. chlamydospora}

This study aimed to assess the susceptibility of nine rootstocks to the fungus $P$. chlamydospora. The rootstocks used were:

- IAC 313 "Tropical" - Golia x Vitis cinerea;
- IAC 572 "Jales" - V. caribaea x 101-14 Mgt (V. riparia x V. rupestris);

- IAC 571-6 "Jundiaî" - V. vinifera (Pirovano 57) x V. caribaea;

- IAC 766 "Campinas" - Ripária do Traviú (106-8 Mgt) x V. caribaea;

- Ripária do Traviú (106-8 Mgt) - V. riparia $\mathrm{x}$ (V. cordifolia x $V$. rupestris);

- Ripária Gloire de Montpellier - seedling of V. riparia;

- Golia - cross of Castel 156-12 (V. vinifera x V. riparia) $\mathrm{x} V$. rupestris;

- $\mathrm{SO} 4-V$. berlandieri x V. riparia;

- Paulsen 1103 - V. berlandieri x V. rupestris.

The experiment was performed in randomized blocks with six replications. Each replication consisted of five pots containing $4.0 \mathrm{~kg}$ of soil and a plant inoculated or not inoculated with the fungus P. chlamydospora of each rootstock. The sanity of the cuttings of each rootstock was attested before installing the test.

The fungus P. chlamydospora (IBVD 01) was isolated from the 'Niagara Rosada' plant grafted on the rootstock Ripária do Traviú from a commercial vineyard in the municipality of

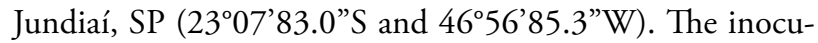
lum of the fungus was produced in Petri dishes containing a PDA medium, and incubated in a growth chamber under $23^{\circ} \mathrm{C}$ for a 12 -hour photoperiod for 30 days.

The methodology to inoculate $P$. chlamydospora in rootstocks was adapted from ESKALEN et al. (2001). The base of the stem $(2 \mathrm{~cm}$ above soil level) was injured with a metallic cork borer $(0.5 \mathrm{~cm})$ and, then, a plug of PDA medium $(0.5 \mathrm{~cm})$ colonized by the fungus was inserted into a circular wound and fixed by sealing the wound with gauze soaked in sterile distilled water and parafilm.

Four months after inoculation, the length of dark streaks caused by $P$. chlamydospora in the vascular system of each rootstock was measured.

\section{Effect of technique combinations on disinfection and rooting of rootstock}

\section{Disinfection}

Eight treatments were established, consisting of the following four techniques (BUENO et al. 2004), complemented or not with hot-water treatment set to $51^{\circ} \mathrm{C}$ for $30 \mathrm{~min}$ (HWT) (GRAMAJE et al., 2009):

1. soil plus kale plants at $37^{\circ} \mathrm{C}$ (biofumigation);

2. soil without kale plants at $37^{\circ} \mathrm{C}$ (solarization);

3. without soil and without kale plants at $37^{\circ} \mathrm{C}$, and

4. without soil and without kale plants at $23^{\circ} \mathrm{C}$ (control).

The experiment was performed in randomized blocks with four replications (rootstock IAC 766 infected with 


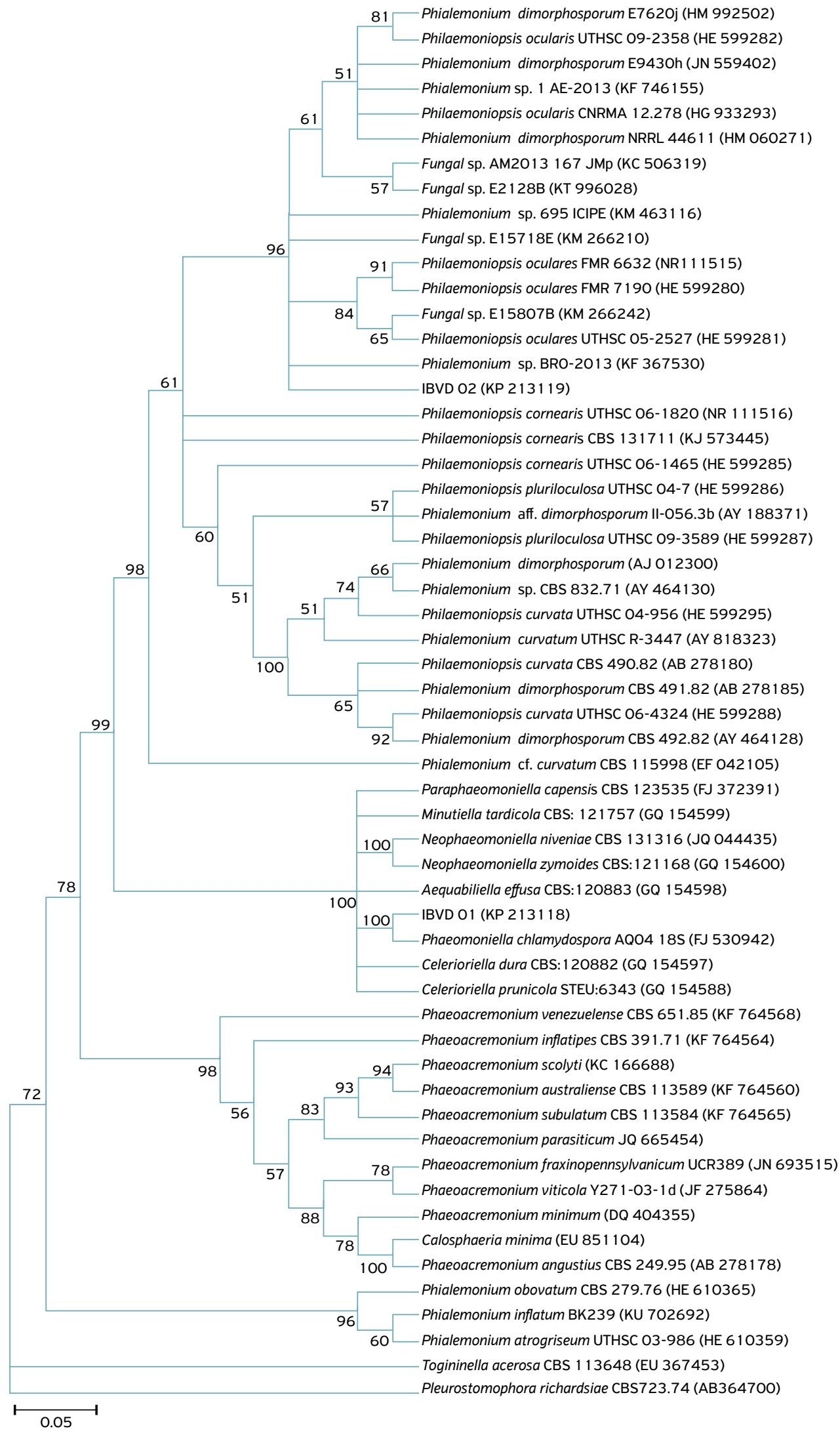

Continue...

Figure 1. Phylogenetic trees showing the relationship between the isolates of fungi detected in 'Niagara Rosada' vine in comparison with the genera and species of fungi isolated from vines and deposited in GenBank-NCBI. The trees were constructed on the basis of the following sequences: (A) ITS-5.8S region - showing condensed tree with $50 \%$ cut-off value; and (B and C) parts of the beta tubulin gene. The isolates Pleurostoma richardsiae (= Pleurostomophora richardsiae) and Conioachaeta lignicola (= Lecythophora lignicola) were used as the outgroup. The accession number of the sequences of the isolates in GenBank-NCBI is given parenthetically. 

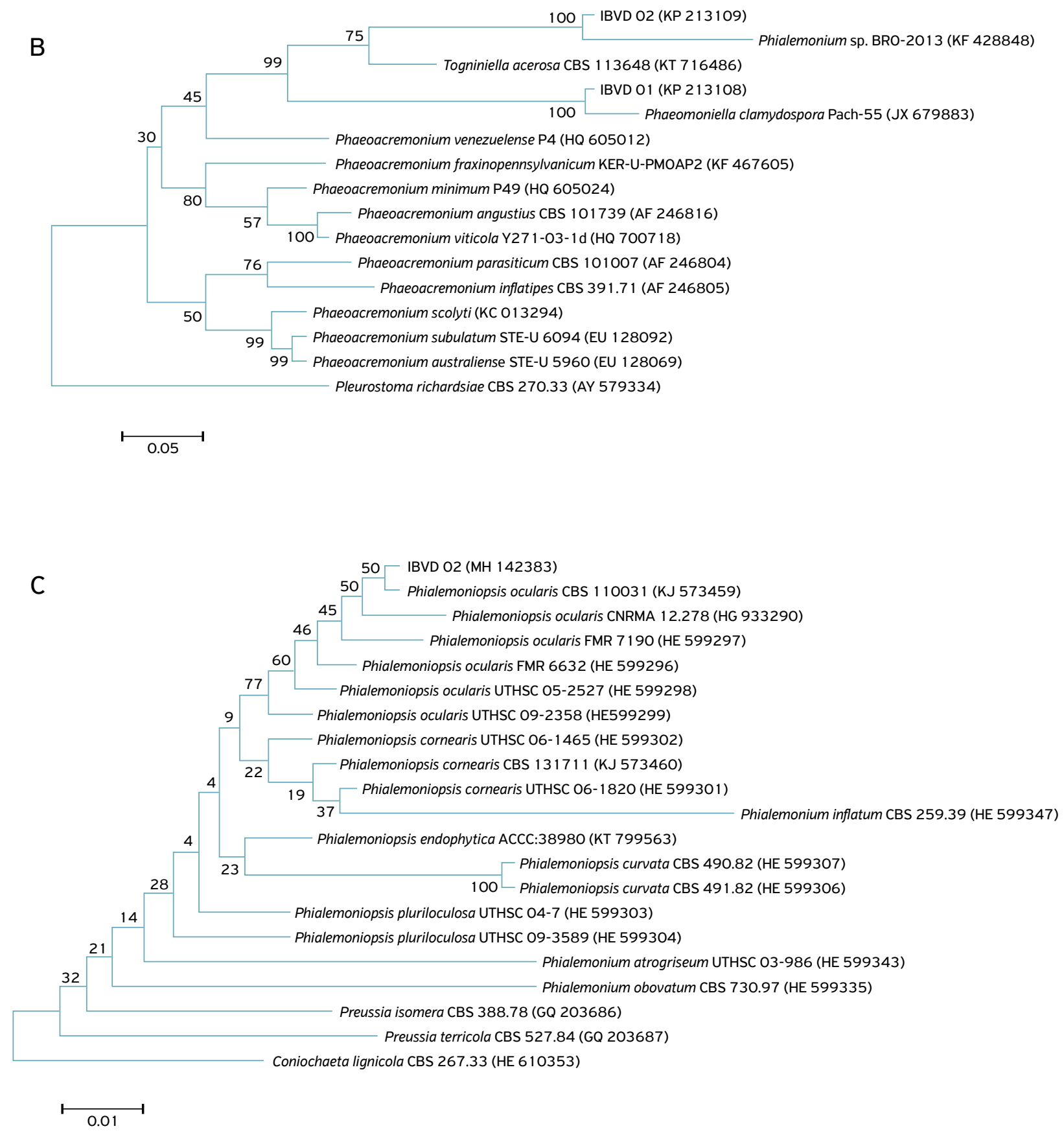

Figure 1. Continuation.

P. chlamydospora) per treatment. Each replication consisted of eight rootstocks (IAC 766) infected with $P$. chlamydospora. To obtain the infected plants, rootstocks (sanity attested) planted in bags with solarized soil were inoculated with the $P$. chlamydospora isolate according to the methodologies of inoculum preparation and inoculation as described for the previous assay (Resistance of rootstocks to the fungus P. chlamydospora). Four months after inoculation, 96 plants were removed from the soil, their root system washed, and eight rootstocks were grouped together and then placed inside one of the two glass bottles that comprise the microcosm (BUENO et al., 2004). All treatments were carried out inside the microcosms and incubated within growth chambers under $37 \pm 2^{\circ} \mathrm{C}$ and $23 \pm 2^{\circ} \mathrm{C}$ for a 12-hour photoperiod for 7, 14, and 21 days (BUENO et al., 2004). After each period, eight rootstocks per treatment were removed from each microcosm and four of them were submitted to additional HWT.

Three identical and independent tests were performed, using an independent microcosm for each period mentioned. The soil used in the experiment (Table 1) was moistened with distilled 
water at a proportion of $20 \%(\mathrm{w} / \mathrm{v})$. For biofumigation, $60 \mathrm{~g}$ of kale (Brassica oleracea var. acephala L.) (Table 2) were crushed and mixed into $3 \mathrm{~kg}$ of soil, providing a $15-\mathrm{cm}$ thick layer of growing medium in the microcosm (BUENO et al. 2004).

For evaluation, after each period of exposition to the treatments, fragments from vascular system of the basal part of each plant (replication) were removed and disinfested superficially, similarly to the colonization test. The fragments were cut into smaller pieces $(0.5 \mathrm{~cm})$ with a sterile scalp, and distributed in a Petri dish containing a PDA medium, with four pieces per dish and 5 dishes per plant. The dishes were incubated in a growth chamber under $23^{\circ} \mathrm{C}$ for a 12 -hour photoperiod for 21 days. Fragments infected with the P. chlamydospora fungus were counted and converted into percentages of infected fragments to compare the efficiency of the treatments.

\section{Rooting}

To assess the effect of the technique combinations on the rooting of the rootstock, eight healthy cuttings containing 2-3 buds (replications) were grouped together and then placed into one of the two glass bottles that comprised the microcosm. The treatments and the methodology to expose the cuttings to the technique combinations were the same as described before (effect of technique combinations on disinfection of rootstock).

After the different exposition periods, the cuttings were planted in a flowerbed $(4 \times 1.5 \mathrm{~m})$, with a spacing of $20 \mathrm{~cm}$ between rows and $12 \mathrm{~cm}$ between plants. After planting, the soil was moistened, and then a mulching was spread on the soil, around the cuttings, in order to maintain appropriate moisture levels. After germination of the first buds, the mulching was removed.

The formation of the radicular system in the cuttings was evaluated 40 days after planting.

\section{Data Analysis}

Colonization data were analyzed by the non-parametric analysis of variance for repeated measurements in independent groups, complemented with the Dunn multiple comparison test (ZAR, 2009), with 5\% significance.

Data from the screening test of rootstocks were subjected to analysis of variance for the experiment in randomized blocks with replicates inside the blocks, complemented with the $\mathrm{T}$ test at $1 \%$ significance (ZAR, 2009).

The data from the disinfection and from the rooting tests were analyzed by the Goodman association test involving contrasts between and within multinomial populations (GOODMAN, 1964; 1965), at 5\% significance.

\section{RESULTS}

\section{Colonization of vines by Petri disease fungi}

'Niagara Rosada' grapevine plants collected from young commercial vineyard were infected by two different fungal species, which were molecularly identified as Phaeomoniella chlamydospora (IBVD01) and Phialemoniopsis ocularis (IBVD02)(Fig. 1).

'Niagara Rosada' plants grafted on rootstock Ripária do Traviú were infected by two pathogens that colonized only the basal part, with significant more colonization by $P$. chlamydospora than by $P$. ocularis. The plants grafted on rootstock IAC 766 were infected just by $P$. chlamydospora, which also colonized only the plant's basal part (Table 3).

\section{Susceptibility of rootstocks to the fungus $P$. chlamydospora}

Control treatment showed no dark streaks; thus, the data on the control were not included in the analyses and in Figure 2.

Golia rootstock was the least susceptible to $P$. chlamydospora, whereas Ripária Glorie, Ripária do Traviú, IAC 766, SO4 and Paulsen 1103 were moderately susceptible, and IAC 572 was the most susceptible (Fig. 2).

Table 1. Mineral composition (macro and micronutrients), $\mathrm{pH}$ and organic matter (OM) of the soil used.

\begin{tabular}{|c|c|c|c|c|c|c|c|c|c|c|c|c|c|c|c|c|}
\hline \multirow{2}{*}{$\underset{\mathrm{CaCl}_{2}}{\mathrm{pH}}$} & \multirow{2}{*}{$\begin{array}{l}\text { O.M. } \\
\mathrm{g} / \mathrm{dm}^{3}\end{array}$} & \multirow{2}{*}{$\underset{\mathrm{mg} / \mathrm{dm}^{3}}{P_{\text {resin }}}$} & $\mathrm{Al}^{3+}$ & $\mathrm{H}+\mathrm{Al}$ & K & $\mathrm{Ca}$ & $\mathrm{Mg}$ & SB & CTC & \multirow{2}{*}{ V\% } & $\mathbf{S}$ & B & $\mathrm{Cu}$ & $\mathrm{Fe}$ & Mn & $\mathrm{Zn}$ \\
\hline & & & \multicolumn{7}{|c|}{$\mathrm{mmol}_{\mathrm{c}} / \mathrm{dm}^{3}$} & & \multicolumn{6}{|c|}{$\mathrm{mg} / \mathrm{dm}^{3}$} \\
\hline 4.3 & 10 & 12 & 5 & 28 & 1.0 & 2 & 2 & 5 & 33 & 15 & 7 & 0.14 & 0.3 & 9 & 2.2 & 0.2 \\
\hline
\end{tabular}

Table 2. Mineral composition (macro and micronutrients) of the kale plants used.

\begin{tabular}{|c|c|c|c|c|c|c|c|c|c|c|c|c|c|}
\hline $\mathbf{N}$ & $\mathbf{P}$ & $\mathbf{K}$ & $\mathrm{Ca}$ & $\mathrm{Mg}$ & $\mathbf{S}$ & C & $\mathrm{Fe}$ & Mn & $\mathrm{Cu}$ & $\mathrm{Zn}$ & B & Al & Humidity \\
\hline \multicolumn{7}{|c|}{ Macronutrients $(g / K g)$} & \multicolumn{6}{|c|}{ Micronutrients (mg/Kg) } & $\%$ \\
\hline 30.6 & 3.3 & 34.3 & 32.5 & 5.8 & 2.4 & 396.3 & 290.5 & 218.5 & 11.3 & 155.6 & 40.9 & 387.3 & 89.2 \\
\hline
\end{tabular}


Table 3. Median values and quartile semi-amplitude of the percentage of incidence of Phaeomoniella chlamydospora and Phialemoniopsis ocularis fungi in samples removed from the vascular system of different parts of 'Niagara Rosada' vines grafted on two different rootstocks.

\begin{tabular}{lcccc} 
Fungi & Rootstocks & \multicolumn{3}{c}{ Parts of plants } \\
\cline { 2 - 5 } Phaeomoniella chlamydospora & Ripária do Traviú & $0.0^{1}( \pm 0.0)^{1} \mathrm{a}^{2} \mathrm{~A}^{3}$ & $0.0( \pm 0.0)$ a A & B \\
\cline { 2 - 5 } & IAC 766 & $0.0( \pm 0.0)$ a A & $0.0( \pm 0.0)$ a A & $50.0( \pm 50.0)$ a B \\
\hline Phialemoniopsis ocularis & Ripária do Traviú & $0.0( \pm 0.0)$ a A & $0.0( \pm 0.0)$ a A & $0.0( \pm 12.50)$ a A \\
\cline { 2 - 6 } & IAC 766 & $0.0( \pm 0.0)$ a A & $0.0( \pm 0.0)$ a A & $0.0( \pm 0.0)$ a A
\end{tabular}

'Median and quartiles semi-amplitude of 60 fragments analyzed; ${ }^{2}$ Lowercase letters compare the rootstocks by fungus in the parts of the plants sampled, according to the Dunn multiple comparison test (ZAR, 2009) at 5\% significance; ${ }^{3}$ Uppercase letters compare the different parts of the plants of the rootstock by fungus, according to the Dunn multiple comparison test (ZAR, 2009) at $5 \%$ significance.

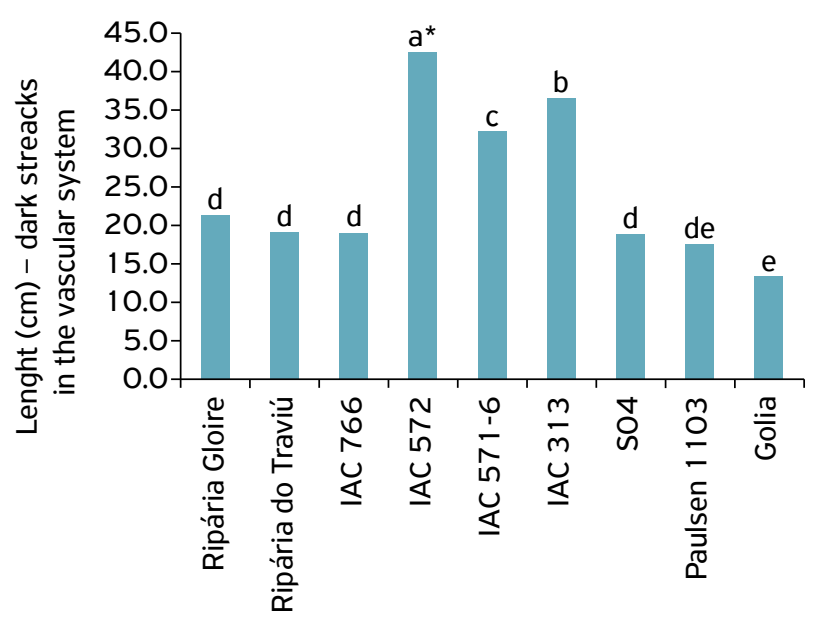

Rootstocks

*Letters compare the different rootstocks for their susceptibility, according to the $T$ test at $1 \%$ probability (ZAR, 2009).

Figure 2. Susceptibility of vine rootstocks to the fungus Phaeomoniella chlamydospora.

\section{Effect of technique combinations on disinfection and rooting of rootstock}

The treatments without hot-water treatment (HWT) did not kill the fungus in the vascular system of the cuttings of the rootstock IAC 766 (Table 4).

The only treatments that suppressed the P. chlamydospora fungus in the vascular tissues of the cuttings of the rootstock IAC 766, in all exposure times tested, were biofumigation and temperature of $37^{\circ} \mathrm{C}$, complemented with HWT. However, the biofumigation and temperature of $37^{\circ} \mathrm{C}$ applied for 14 days and complemented with HWT suppressed the fungus and allowed rooting on $75 \%$ of the rootstock cuttings (Tables 4 and 5). This rate of rootstock rooting is acceptable for later planting and production of healthy rootstock mother plants.

The HWT treatment $\left(51^{\circ} \mathrm{C}\right.$ for $\left.30 \mathrm{~min}\right)$ tested solely $\left(23^{\circ} \mathrm{C}\right.$ complemented with HWT) did not affect the rootstock cuttings
Table 4. Percentage of incidence of Phaeomoniella chlamydospora in samples of the vascular system of the basal part of the rootstock IAC 766, submitted to different treatments for different periods, with and without added hot-water treatment (HWT).

\begin{tabular}{|c|c|c|c|}
\hline Treatment & $\begin{array}{c}\text { HWT } \\
51^{\circ} \mathrm{C} / \\
30 \mathrm{~min} .\end{array}$ & $\begin{array}{l}\text { Exposure } \\
\text { time to } \\
\text { treatment } \\
\text { (days) }\end{array}$ & $\begin{array}{l}\text { Incidence } \\
(\%)\end{array}$ \\
\hline \multirow{3}{*}{$\begin{array}{l}\text { Soil + kale at } 37^{\circ} \mathrm{C} \\
\text { "Biofumigation" }\end{array}$} & \multirow{12}{*}{ Without } & 7 & $25.0^{1}$ b B $\beta$ \\
\hline & & 14 & 6.3 а $\mathrm{AB} \alpha$ \\
\hline & & 21 & 7.5 ab $A \alpha$ \\
\hline \multirow{3}{*}{$\begin{array}{l}\text { Soil - kale at } 37^{\circ} \mathrm{C} \\
\text { "Solarization" }\end{array}$} & & 7 & 20.0 a B $\beta$ \\
\hline & & 14 & 1.3 a A $\alpha$ \\
\hline & & 21 & 45.0 b B $\beta$ \\
\hline \multirow{3}{*}{$\begin{array}{l}\text { Without soil and } \\
\text { without kale at } 37^{\circ} \mathrm{C}\end{array}$} & & 7 & 2.5 a A $\alpha$ \\
\hline & & 14 & 16.3 a $\mathrm{B} \beta$ \\
\hline & & 21 & 15.0 a $A \beta$ \\
\hline \multirow{3}{*}{$\begin{array}{l}\text { Without soil and } \\
\text { without kale at } 23^{\circ} \mathrm{C}\end{array}$} & & 7 & 0.0 a A $\alpha$ \\
\hline & & 14 & 13.8 b AB $\alpha$ \\
\hline & & 21 & $2.5 \mathrm{ab} A \alpha$ \\
\hline \multirow{3}{*}{$\begin{array}{l}\text { Soil + kale at } 37^{\circ} \mathrm{C} \\
\text { "Biofumigation" }\end{array}$} & \multirow{12}{*}{ With } & 7 & 0.0 a A $\alpha$ \\
\hline & & 14 & 0.0 a $\mathrm{A} \alpha$ \\
\hline & & 21 & 0.0 a $\mathrm{A} \alpha$ \\
\hline \multirow{3}{*}{$\begin{array}{l}\text { Soil - kale at } 37^{\circ} \mathrm{C} \\
\text { "Solarization" }\end{array}$} & & 7 & 0.0 a A $\alpha$ \\
\hline & & 14 & 0.0 a A $\alpha$ \\
\hline & & 21 & 1.3 a $\mathrm{A} \alpha$ \\
\hline \multirow{3}{*}{$\begin{array}{l}\text { Without soil and } \\
\text { without kale at } 37^{\circ} \mathrm{C}\end{array}$} & & 7 & 0.0 a $\mathrm{A} \alpha$ \\
\hline & & 14 & 0.0 a $\mathrm{A} \alpha$ \\
\hline & & 21 & 0.0 a A $\alpha$ \\
\hline \multirow{3}{*}{$\begin{array}{l}\text { Without soil and } \\
\text { without kale at } 23^{\circ} \mathrm{C}\end{array}$} & & 7 & 2.5 a $A \alpha$ \\
\hline & & 14 & 2.5 a $A \alpha$ \\
\hline & & 21 & 1.3 а $\mathrm{A} \alpha$ \\
\hline
\end{tabular}

Lowercase letters: comparison of different periods by fixing the thermotherapy and treatment; Uppercase letters: comparison of treatments by fixing the thermotherapy and the period; Greek letters: comparison of thermotherapy by fixing the treatment and the period. The comparisons were done in accordance with the Goodman association test (GOODMAN, 1964; 1965) at 5\% significance 'Medium of 80 fragments analyzed. 
for root formation, but also did not eliminate P. chlamydospora from plants (Tables 4 and 5).

The biofumigation for 21 days followed or not by HWT, and the temperature of $37^{\circ} \mathrm{C}$ followed by HWT treatments hampered the root formation in the rootstock cuttings, resulting in $0 \%, 25 \%$ and $25 \%$ of root formation for these treatments (Table 5). Thus, the application of these treatments for periods over 14 days, complemented with HWT, negatively affected the root formation in the cuttings.

\section{DISCUSSION}

This is the first report of the Phialemoniopsis ocularis fungus in young vineyards in Brazil. The P. chlamydospora fungus that was found infecting 'Niagara Rosada' grafted on two different rootstocks is often the main responsible for Petri disease (HALLEEN et al., 2007; MUGNAI et al., 1999). This fungus had already been found in Brazil, infecting the rootstock SO4 (CORREIA et al., 2013).

HALLEEN et al. (2007) isolated Phialemoniopsis curvata (=Phialemonium curvatum) from vascular tissues from an asymptomatic vines nursery, and stated that this fungus may cause decline in nurseries or young vineyards. According to the phylogenetic tree of the present study (Fig. 1), the fungus Phialemonium curvatum (EF042105) found by HALLEEN et al. (2007) should belong to the Phialemoniopsis cornearis species.

The genus Phialemoniopsis was created by PERDOMO et al. (2013) to accommodate the Phialemoniopsis curvata (=Phialemonium curvatum) and Phialemoniopsis ocularis (=Sarcopodium oculorum) fungi, and two new species, Phialemoniopsis cornearis and Phialemoniopsis pluriloculosa. Interestingly, the GenBank sequences available for the P. ocularis species are related to specimens that cause opportunistic infections in humans and in other animals. A review about Phaeoacremonium species involved in Petri disease and Esca shows that some species of Phaeoacremonium are able to infect Vitis vinifera and humans (MOSTERT et al., 2006). According to HALLEEN et al. (2007), the relative importance of $P$. cornearis and $P$. ocularis to the decline in grapevines should be confirmed by assessing the frequency of incidence of these fungi on diseased grapevines with different ages, which grew in different places.

P. chlamydospora was found predominantly in the basal part of 'Niagara Rosada' vines (rootstocks Ripária do Traviú and IAC 766), confirming results obtained by ABREO et al. (2011) and LORENA et al. (2001). According to ABREO et al. (2011), the P. chlamydospora fungus may also be found in other parts of grapevine such as in the apical part. However, the rootstock is the main target for Petri disease fungi. Thus, studies are still necessary to find rootstocks with high level of resistance to Petri disease or techniques that ensure the total disinfection of the rootstock cuttings.

Reviewing on Phaeoacremonium species and on plant susceptibility to the Petri and Esca diseases, MOSTERT et al. (2006) emphasized the absence of rootstocks or scions with immunity or with a high level of resistance. In agreement with MOSTERT et al. (2006), none of the rootstocks tested in our study were immune or showed high level of resistance to $P$. chlamydospora.

The rootstocks Paulsen 1103 and Richter 110, artificially inoculated with $P$. chlamydospora, were more susceptible to the fungus compared to the $V$. vinifera cultivars, Chardonnay and Aglianico (ZANZOTTO et al., 2008). Similar results were obtained in Australia, where seven rootstocks (Ramsey, 99 Richter, Schwarzmann, Kober 5BB, P 1103, 101-14 Millardet and SO4) were more susceptible to P. chlamydospora than five cultivars of $V$. vinifera (Merlot, Cabernet Sauvignon,

Table 5. Percentage of root formation in the rootstock IAC 766 cuttings submitted to disinfection in different periods, with and without added hot-water treatment (HWT).

\begin{tabular}{|c|c|c|c|c|}
\hline \multirow{2}{*}{ Treatment } & \multirow{2}{*}{$\begin{array}{c}\text { HWT } \\
51^{\circ} \mathrm{C} / \\
30 \mathrm{~min} .\end{array}$} & \multicolumn{3}{|c|}{ Exposure time (days) } \\
\hline & & 7 & 14 & 21 \\
\hline \multirow{2}{*}{$\begin{array}{l}\text { Soil + kale at } 37^{\circ} \mathrm{C} \\
\text { "Biofumigation" }\end{array}$} & Without & $100.0^{1}$ a $A \beta$ & 100.0 a $A \beta$ & 25.0 a $\mathrm{A} \alpha$ \\
\hline & With & 75.0 a $A \beta$ & 75.0 a A $\beta$ & 0.0 a A $\alpha$ \\
\hline \multirow{2}{*}{$\begin{array}{l}\text { Soil - kale at } 37^{\circ} \mathrm{C} \\
\text { "Solarization" }\end{array}$} & Without & 75.0 a $\mathrm{A} \alpha$ & 100.0 a $\mathrm{A} \alpha$ & 50.0 а $\mathrm{AB} \alpha$ \\
\hline & With & 50.0 a $\mathrm{A} \alpha$ & 75.0 a $\mathrm{A} \alpha$ & 50.0 a $\mathrm{AB} \alpha$ \\
\hline \multirow{2}{*}{$\begin{array}{l}\text { Without soil and } \\
\text { without kale at } 37^{\circ} \mathrm{C}\end{array}$} & Without & 75.0 a $\mathrm{A} \alpha$ & 50.0 a $\mathrm{A} \alpha$ & 100.0 b B $\alpha$ \\
\hline & With & 100.0 a $A \beta$ & 75.0 a $A \alpha \beta$ & 25.0 a A $\alpha$ \\
\hline \multirow{2}{*}{$\begin{array}{l}\text { Without soil and } \\
\text { without kale at } 23^{\circ} \mathrm{C}\end{array}$} & Without & 100.0 a A $\alpha$ & 100.0 a A $\alpha$ & 100.0 a B $\alpha$ \\
\hline & With & 75.0 a $\mathrm{A} \alpha$ & 100.0 a A $\alpha$ & 100.0 a B $\alpha$ \\
\hline
\end{tabular}

'Medium of four cuttings analyzed. Lowercase letters: comparison of thermotherapy (with and without) by fixing the treatment and the period; uppercase letters: comparison of treatments by fixing the thermotherapy and the period; Greek letters: comparison of different periods ( 7,14 and 21 days) by fixing treatment and thermotherapy. The comparisons were done in accordance with the Goodman association test (GOODMAN, $1964 ; 1965)$ at $5 \%$ significance. 
Pinot Noir, Shiraz PT10 and Shiraz PT23) (WALLACE et al., 2004). These studies show that $V$. vinifera materials are indeed less susceptible to the $P$. chlamydospora fungus compared to the rootstocks. Furthermore, GRAMAJE et al. (2010) suggested that grapevine rootstock crosses of $V$. riparia $\mathrm{x} V$. berlandieri could be less susceptible to the patogens $C$. luteo-olivacea, Phaeoacremonium spp. and P. chlamydospora, which are involved with Petri disease in young vines.

In the present study, the rootstocks with low and moderate susceptibility come from Vitis riparia, V. rupestris, V. berlandieri and $V$ vinifera, which suggests that their genetic backgrounds from species of Vitis can be responsible for the least susceptibility to $P$. chlamydospora. New breeding studies are needed to obtain a rootstock with a satisfactory resistance level to Petri disease pathogens.

In agreement with ROONEY; GLUBER (2001), the application of HWT at $51^{\circ} \mathrm{C}$ for 30 min solely as a curative measure is not sufficient to control $P$. chlamydospora and $P$. inflatipes from dormant material. On the other hand, GRAMAJE et al. (2009), when applying HWT with temperatures above $50^{\circ} \mathrm{C}$ for different periods, managed to eliminate P. chlamydospora from vine materials, but the process affected the sprouting and the weight of branches of the combination Temp - scion and 161-49 C - rootstock. In the present study, HWT $\left(51^{\circ} \mathrm{C}\right.$ for $30 \mathrm{~min})$ tested as sole treatment $\left(23^{\circ} \mathrm{C}\right.$ followed by HWT) did not affect the rootstock cuttings for root formation, but also did not eliminate $P$. chlamydospora from the plants.

The biofumigation or temperature of $37^{\circ} \mathrm{C}$ treatments should be applied for 14 days, followed by the complementary treatment of HWT at $51^{\circ} \mathrm{C}$ for $30 \mathrm{~min}$ in order to eliminate P. chlamydospora from rootstock cuttings without affect the rooting. The interaction among different treatments such as biofumigation plus HWT can be more efficient to control the Petri disease fungi in rootstock cuttings compared to HWT tested as a sole technique.

Once the efficiency of these new techniques is validated, the healthy and normal cuttings can be used by growers to obtain healthy rootstock mother plants and, consequently, produce healthy nursery plants, eliminating the following problems reported by other authors:

- transmission of the Petri disease fungi in nurseries through the use of infected mother plants (MOSTERT et al., 2006), and

- use of HWT with temperatures above $50^{\circ} \mathrm{C}$ for long periods, which eradicates the fungus $P$. chlamydospora, but that can damage the plants (GRAMAJE et al., 2009).

\section{CONCLUSION}

In conclusion, $P$. chlamydospora and $P$. ocularis colonized prevalently the basal part of 'Niagara Rosada' plants, denoting colonization of the rootstock. P. ocularis was detected by the first time in young vineyards in Brazil. Golia was the least susceptible rootstock to $P$. chlamydospora, and IAC 572 was the most susceptible. Biofumigation or temperature of $37^{\circ} \mathrm{C}$ applied for 7-14 days and followed by HWT at $51^{\circ} \mathrm{C}$ for $30 \mathrm{~min}$, when used as treatments, suppressed $P$. chlamydospora in the rootstock cuttings without hampering the rooting. Meanwhile, new studies are necessary to validate the efficiency these disinfection techniques.

\section{ACKNOWLEDGEMENTS}

The authors would like to thank Coordenação de Aperfeiçoamento de Pessoal de Nível Superior - Brazil (CAPES) for partial financial support received - Finance Code 001. The authors also would like to thank Mr. Daniel Fernando Miqueletto (Agricultural Engineer of City Council of Louveira, São Paulo state, Brazil) for the financial support received (FUNDAG - IB - Porta Enxertos 1018), and Mr. Fernando Perez, owner of the vineyard (Jundiaí city, São Paulo state, Brazil), for authorization to collect 'Niagara Rosada' grapevines with Petri disease.

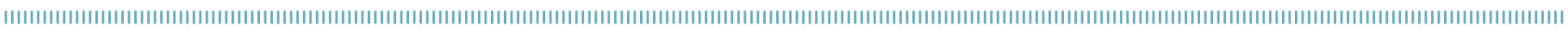
REFERENCES

ABREO, E.; MARTÍNEZ, S.; BETTUCCI, L.; LUPO, S. Phaeomoniella chlamydospora and Phaeoacremonium spp. in grapevines from Uruguay. Phytopathologia Mediterranea, Bologna, v.50, p.577-585, 2011 . http://dx.doi.org/10.14601/ Phytopathol_Mediterr-8682

AROCA, A.; RAPOSO, R. Pathogenicity of Phaeoacremonium species on grapevines. Journal of Phytopathology, Berlin, v.157, p.413-419, 2009. http://dx.doi.org/10.1111/j.1439-0434.2008.01513.x

AROCA, Á.; GRAMAJE, D.; ARMENGOL, J.; GARCÍA-JIMÉNEZ, J.; RAPOSO, R. Evaluation of the grapevine nursey propagation process as a source of Phaeoacremonium spp. and Phaeomoniella chlamydospora and occurrence of trunk disease pathogens in rootstock mother vines in Spain. European Journal of Plant Pathology, Dordrecht, v.126, p.165-174, 2010. http://dx.doi. org/10.1007/s10658-009-9530-3

BUENO, C.J.; AMBRÓSIO, M.M.Q.; SOUZA, N.L.; CERESINI, P.C. Controle de Fusarium oxysporum f.sp. lycopersici raça 2, Macrophomina phaseolina e Sclerotium rolfsii em microcosmo simulando solarização com prévia incorporação de couve (Brassicae oleracea var. acephala L.). Summa Phytopathologica, Botucatu, v.30, n.3, p.356-363, 2004. 
CORREIA, K.C.; CÂMARA, M.P.S.; BARBOSA, M.A.G.; SALES JR.; R., AGUSTÍ-BRISACH, C.; GRAMAJE, D.; LÉON, M.; GARCÍA-JIMÉNEZ, J.; ABAD-CAMPOS, P.; ARMENGOL, J.; MICHEREFF, S.J. Fungal trunk pathogens associated with table grapes decline in North-eastern Brazil. Phytopathologia Mediterranea, Bologna, v.52, n.2, p.380-387, 2013.

DOYLE, J.J.; DOYLE, J.L. A rapid DNA isolation procedure for small quantities of fresh leaf tissue. Phytochemical Bulletin, Sussex, v.19, n.1, p.11-15, 1987.

EDGAR, R.C. Muscle: multiple sequence alignment with high accuracy and high throughput. Nucleic Acids Research, Oxford, v.32, n.5, p.1792-1797, 2004. http://dx.doi.org/10.1093/nar/gkh340

ESKALEN, A.; GLUBER, W.D.; KHAN, A. Rootstock susceptibility to Phaeomoniella chlamydospora and Phaeoacremonium spp. Phytopathologia Mediterranea, Bologna, v.40, p.S433-S438, 2001. http://dx.doi.org/10.14601/Phytopathol_Mediterr-1636

GARRIDO, L.R.; SÔNEGO, O.R.; GOMES, V.N. Fungos Associados com o Declínio e Morte de Videiras no Estado do Rio Grande do Sul. Fitopatologia Brasileira, Brasília, v.29, n.3, p.322-324, 2004.

GLASS, N.L.; DONALDSON, G.C. Development of primer sets designed for use with the PCR to amplify conserved genes from filamentous ascomycetes. Applied and Environmental Microbiology, Washington, v.61, n.4, p.1323-1330, 1995.

GOODMAN, L. A. Simultaneous confidence intervals for contrasts among multinomial populations. Annals of Mathematical Statistics, Ann Arbor, v.35, p.716-725, 1964.

GOODMAN, L.A. On simultaneous confidence intervals for multinomial proportions. Technometrics, Washington, v.7, n.2, p.247-254, 1965. http://dx.doi.org/10.1080/00401706.1 965.10490252

GOPI, R.; AVASTH, R.K.; YADAV, A.; KALITA, H. Biological soil disinfestation and biofumigation alternatives for chemical fumigation in organic farming. Advances in Plants $\odot$ Agriculture Research., v.4, n.2, p.00135, 2016. http://dx.doi.org/10.15406/ apar.2016.04.00135

GRAMAJE, D.; ARMENGOL, J.; SALAZAR, D.; LÓPEZ-CORTÉS, I.; GARCÍA-JIMÉNEZ, J. Effect of hot-water treatments above $50^{\circ} \mathrm{C}$ on grapevine viability and survival of Petri disease pathogens. Crop Protection, Guildford, v.28, n.3, p.280-285, 2009. http:// dx.doi.org/10.1016/j.cropro.2008.11.002

GRAMAJE, D.; GARCÍA-JIMÉNEZ, J.; ARMENGOL, J. Field evaluation of Grapevine Rootstocks inoculated with Fungi associated with Petri disease and Esca. American Journal of Enology and Viticulture, Davis, v.61, n.4, p.512-520, 2010.

GRAMAJE, D.; ARMENGOL, J. Fungal trunk pathogens in the grapevine propagation process: potential inoculums sources, detection, identification and management strategies. Plant Disease, Saint Paul, v.95, n.9, p.1040-1055, 2011 . http:// dx.doi.org/10.1094/PDIS-01-11-0025

GRAMAJE, D.; MOSTERT, L.; ARMENGOL, J. Characterization of Cadophora luteo-olivacea and C. melinii isolates obtained from grapevines and environmental samples from grapevine nurseries in Spain. Phytopathologia Mediterranea, Bologna, v.50, p.S1 12S126, 2011.

HALLEEN, F.; MOSTERT, L.; CROUS, P.W. Pathogenicity testing of lesser-known vascular fungi of grapevines. Australasian Plant Pathology, Clayton, v.36, p.277-285, 2007. https://doi. org/10.1071/AP07019

LAZAROTTO, M.; BOVOLINI, M.P.; MUNIZ, M.F.B.; HARAKAVA, R.; REINIGER, L. R.S.; SANTOS, A.F. Identification and characterization of pathogenic Pestalotiopsis species to pecan tree in Brazil. Pesquisa Agropecuária Brasileira, Brasília, v.49, p.440-448, 2014. http://dx.doi.org/10.1590/SO100-204X2014000600005

LORENA, T.; CALAMASSI, R.; MORI, B.; MUGNAI, L.; SURICO, G. Phaemoniella chlamydospora-grapevine interaction: histochemical reactions to fungal infection. Phytopathologia Mediterranea, Bologna, v.40, n.3, p.S400-S406, 2001.

MOSTERT, L.; HALLEEN, F.; FOURIE, P.; CROUS, P.W. A review of Phaeoacremonium species involved in Petri disease and esca of grapevines. Phytopathologia Mediterranea, Bologna, v.45, p.S12-S29, 2006.

MUGNAI, L.; GRANITI, A.; SURICO, G. Esca (black measles) and brown woodstreaking: two old and elusive diseases of grapevine. Plant Disease, Saint Paul, v.83, n.5, p.404-418, 1999. https:// doi.org/10.1094/PDIS.1999.83.5.404

PERDOMO, H.; GARCÍA, D.; GENÉ CANO, J.J.; SUTTON, D.A.; SUMMERBELL, R.; GUARRO, J. Phialemoniopsis, a new genus of Sordariomycetes, and new species of Phialemonium and Lecythophora. Mycologia, New York, v.105, n.2, p.398-421, 2013. https://doi.org/10.3852/12-137

ROONEY, S.; GUBLER, W.D. Effect of hot water treatments on eradication of Phaeomoniella chlamydospora and Phaeoacremonium inflatipes from dormant grapevine wood. Phytopathologia Mediterranea, Bologna, v.40, n.3, p.S467-S472, 2001. http:// dx.doi.org/10.14601/Phytopathol_Mediterr-1617

SCHMITZ, A.; RIESNER, D. Purification of nucleic acids by selective precipitation with polyethylene glycol 6000 . Analytical Biochemistry, New York, v.354, n.2, p.31 1-313, 2006. http:// dx.doi.org/10.1016/j.ab.2006.03.014

WALLACE, J.; EDWARDS, J.; PASCOE, I.G.; MAY. P. Phaeomoniella chlamydospora inhibits callus formation by grapevine rootstock and scion cultivars. Phytopathologia Mediterranea, Bologna, v.43, p.151-152, 2004.

WHITE, T.J.; BRUNS, T.; LEE, S.; TAYLOR, J. Amplification and direct sequencing of fungal ribosomal RNA genes for phylogenetics. In: INNIS, M.A.; GELFAND, D.H.; SHINSKY, J.J.; WHITE, T.J. (Eds.). PCR protocols: a guide to methods and applications. San Diego: USA. Academic., 1990. p.315-322.

ZANZOTTO, A.; GARDIMAN, M.; LOVAT, L. Effect of Phaeomoniella chlamydospora and Phaeoacremonium sp. on in vitro grapevine plants. Scientia Horticulturae, Amsterdam, v. 1 16, n.4, p.404-408, 2008. http://dx.doi.org/10.1016/j.scienta.2008.03.002

ZAR, J.H. (Ed.). Biostatistical analysis. 5 ed. New Jeresey: Practice-Hall, 2009. 960p.

This is an open access article distributed under the terms of the Creative Commons license 